\title{
The Issue of Care Given to Premature Infants in the Provincial Hospital Center of Missour
}

\author{
Loubna Doukkali', Fatima Zahra laamiri², Nada Bennani Mechita3 ${ }^{3}$, Laila Lahlou', \\ Mouna Habibi ${ }^{1}$, Amina Barkat ${ }^{1}$ \\ ${ }^{1}$ Faculty of Medicine and Pharmacy of Rabat, Research Team in Maternal and Child Health and Nutrition, \\ Mohammed V University, Rabat, Morocco \\ ${ }^{2}$ Higher Institute of Nursing Professions and Technical Health Morocco/ Research Team in Maternal and Child \\ Health and Nutrition, Mohammed V University at Souissi, Rabat, Morocco \\ ${ }^{3}$ Laboratory of Biostatistics and Clinical Research and Epidemiology, Faculty of Medicine and Pharmacy, Rabat, \\ Morocco \\ Email: barakatamina@hotmail.fr, I_doukkali@yahoo.fr, fatilamir1970@yahoo.fr, nadaben7@gmail.com, \\ drlailalahlou@ymail.com, habibimouna@gmail.com
}

Received 10 May 2016; accepted 21 May 2016; published 24 May 2016

Copyright (C) 2016 by authors and Scientific Research Publishing Inc.

This work is licensed under the Creative Commons Attribution International License (CC BY). http://creativecommons.org/licenses/by/4.0/

(c) (i) Open Access

\section{Abstract}

Background: Preterm birth is common in Morocco and it's around 8\%. Several management rules of taking care of preterm infants have been developed but have not been put into action. The geographical inaccessibility to specialized hospitals and the weakness of the reception capacity of the care centers hinder the management of the complications associated with preterm birth. Purpose: The present study is designed to present some epidemiological data of preterm births within the Provincial Hospital Center of Missour during 2012 and to discuss the various problems emerging in the management of treatment and care. Materials and Methods: Retrospective study of preterm births in the maternity ward in the Hospital of Missour during 2012. Results: 37 preterm births among $1121(3.3 \%)$ have been analyzed (51.3\% severe premature infants, $45.9 \%$ late preterm infants and $2.7 \%$ extremely premature infants). $64.2 \%$ are originally from difficult areas to reach during winter. All mothers have received upon arrival at the maternity a corticosteroid and calcium antagonists (Adalate*) and an antibiotic treatment to those with a positive infectious anamnesis found in half of the women. We have recorded 3 twin pregnancies and 2 gravidic toxemias. Only 21 babies have been given back to their mothers (namely 56.7\%). 5 premature infants (namely 13\%) have been referred to the university hospital center of Fez ( 2 respiratory distress, a malformation and 2 severe premature births) given that there is an absence of a specialized care unit at the hospital, knowing that no baby has received neither surfactant nor caffeine at birth. 14 premature babies (namely $37.8 \%$ ) have been transferred to the pediatric unit with a total death rate of $16.2 \%$ ( 6 premature) mainly related to neonatal infection and to suffering of the hyaline membranes disease. Conclusion: We emphasize the interest of prevention programs which de- 
mand an early diagnosis of preterm birth threats and monitoring high-risk pregnancies, improving the medical care given to low-weight premature by creating "Kangaroo" units at a regional level and the targeting of measures for rural and under-covered areas.

\section{Keywords}

\section{Premature Infant, Rural Area, Prevention, “Kangaroo Care”}

\section{Introduction}

Preterm birth is defined as birth occurring before 37 weeks of pregnancy calculated from the first day of the last period [1]. There are three groups according to the term of birth: great premature less than 28 weeks of amenorrhea, great premature equal or less than 32 weeks of amenorrhea, premature less than 37 weeks of amenorrhea [2] [3].

It is nowadays a priority for obstetric and neonatal teams because of its infrequency (7\% to 14\%) while, its high incidence rate (60\% to $75 \%)$ responsible for neonatal deaths [3] [4]. Eleven million preterm infants are born each year around the world [3].

In developed countries, particularly France and the United States, the preterm birth rate has increased over the last decade mainly due to the increase of the number of twin pregnancies with techniques of medically assisted procreation [5] [6]. In developing countries, the preterm birth rate is quite high especially in Africa [7]. According to the World Health Organization, 3 million newborns die each year from complications related to pregnancy or childbirth and $99 \%$ of these deaths occur in developing countries [8]. Nearly $40 \%$ of all preterm births occur before 34 weeks of gestation, and $20 \%$ of them before 32 weeks [6].

The events leading to preterm birth are not fully understood. The causes of prematurity include medical conditions of the mother or fetus (caused prematurity), genetic factors, environmental causes, socioeconomic factors and iatrogenic prematurity [9] [10].

In developing countries, the management of preterm remains difficult because of the very limited resources including specialized units which are not existing and so inefficient. Immediate support requires special medical care because of their vulnerability and the immaturity of their vital functions (heart, lungs, kidneys, gastrointestinal tract, brain, ....), whatever the term of birth is [3].

In order to reduce the frequency of preterm birth and to contribute to the reduction of neonatal mortality particularly in resources with reduced structures, we propose to present some epidemiological data of premature infants in the Missour provincial hospital specifying the causes of morbidity in this category of newborns and offer medical and social preventive measures adapted to improve the quality of care for premature infants.

\section{Patients and Methods}

\subsection{The Location of the Study}

Our study took place in the maternity ward of the provincial hospital in Missour. This municipality is considered as the capital of the province of Boulemane which is a predominantly rural area in the Moroccan region of FezBoulemane. It covers an area of $14.600 \mathrm{~km}^{2}$ and has a population of about 202.000 inhabitants including 23.250 inhabitants that occupy the communes which makes it difficult to gain access to health facilities during winter.

\subsection{Patients}

We conducted an analytical and comparative study at the maternity ward of the provincial hospital in the urban commune of Missour from January 1, 2012 to December 31, 2012.

Inclusion criteria

We have included all premature infants born in this structure as well as all deliveries occurred during the same period of this study.

\section{Exemption criteria}

All unusable files have been excluded from the study. 


\subsection{Data Information}

To define the main causes of morbidity in premature infants in the province, pediatrician filled up a data collection form including socio-demographic and obstetric data of the mothers (origin of mother, mother age, pregnancy care, gestity-parity, term of pregnancy, infectious anamnesis and mode of delivery), epidemiological data information about new born (apgar at birth, sex, gestational age and weight) and the immediate fate of the preterm babies (status of the child at birth, birth form). The immediate fate is defined by analyzing the evolution of the premature infants within the first 24 hours after birth. Data information about neonatal complication (Perinatal asphyxia, respiratory distress, neonatal mortality, premature infants referred, premature infants hospitalized in pediatrics) were also collected from maternity record.

\subsection{Definition of the Parameters Studied}

A rural area of difficult access corresponds to a sanitary health area enclave because of the lack or dramatic deterioration of the road network. Generally badly served by Government, health care facilities in such areas are not modern and lacking of well-qualified professionals. It is any area located between 80 and $400 \mathrm{~km}$ in good weather conditions from a first referral hospital [11]. In this context, an area with difficult access is taken into consideration when there is a distance starting from 8 - $10 \mathrm{~km}$ to reach a sanitary facility with difficult access.

Menstrual age is a measure of the age of a pregnancy determined by directly calculating the days since the beginning of the last menstrual period or by echography. The study was also based on the morphological criteria of FARR as well as on the Dubowitz score to determine the term. Prematurity is a birth occurring before 37 weeks of gestation.

Low birth weight is defined by a measured weight of the newborn lower than the 10th percentile of the reference curve of B. Lorey, F. Lefort for gestational age.

Respiratory distress was defined by the presence of signs of struggle, regardless of its etiology.

Perinatal asphyxia has been defined by an apgar score $<7$ during the first 5 minutes of life.

\subsection{Ethical Consideration}

Respect for the anonymity and confidentiality of information was strictly adhered to.

\subsection{The Statistical Analysis}

The statistical study has been developed by the team of the Department of Biostatistics at the Faculty of Medicine and Pharmacy of Rabat.

The results have been presented in staffing and percentages.

The comparison of the percentages has been carried out by the test of khi2 or by the Fisher test.

The degree of statistical significance was retained for a $\mathrm{P}<0.05$.

\section{Results}

\subsection{Characteristics of All the Parturient Women}

1108 parturient women admitted for delivery in the maternity ward of the provincial hospital center were included in this study and divided into two populations: one population of 1074 women including 10 twin pregnancies with a total of 1084 newborns at term and another population of 34 women including 3 twin pregnancies with a total of 37 premature infants.

\subsection{Socio-Demographic and Obstetric Characteristics of Parturient Women with Premature Infants (Table 1(a))}

The maternal age varied by an age group between 18 and 40 years. One woman was 18 years and 6 were more than 35 years. $82.35 \%$ of the women were under 35 years.

The analysis of records revealed a slight predominance of multiparous women $(52.9 \%)$ and those whose term of pregnancy is less than 33 weeks of amenorrhea. $64.7 \%$ of women have been monitored. The majority of the parturient women were delivered vaginally (97.1\%). No particular past history was mentioned in the parturient 
women records. All mothers have received upon admitted to the maternity a combination of corticosteroid and calcium antagonists. We noted 35 (94.5\%) spontaneous deliveries related to premature rupture of the fetal membranes in 15 cases (40\%) and a twinning in 3 cases (8\%). A toxemia of pregnancy was noted in 2 cases (5.4\%) which justified an early delivery. A positive infectious anamnesis was found in 21 cases (56.8\%).

\subsection{Epidemiological and Clinical Characteristics of Premature Infants (Table 1(b))}

The preterm birth rate was 3.3\%, that is to say 37 premature infants out of a total of 1121 live births. Menstrual

Table 1. (a) Socio-demographic and obstetrical characteristics of parturient with premature infants ${ }^{\mathrm{a}}$; (b) Medical characteristics of premature infants ${ }^{\mathrm{a}}$.

(a)

\begin{tabular}{lc}
\hline Characteristics & Parturient $^{\mathbf{a}} \mathbf{n}=\mathbf{3 4}$ \\
\hline $\begin{array}{l}\text { Origin of mother } \\
<50 \mathrm{~km}\end{array}$ & $17(50.0 \%)$ \\
$>50 \mathrm{~km}$ & $17(50.0 \%)$ \\
$\begin{array}{l}\text { Age } \\
<35 \text { years }\end{array}$ & $28(82.35 \%)$ \\
$>35$ years & $6(17.64 \%)$ \\
Gestity-parity & \\
Primiparous & $16(47.1 \%)$ \\
Mutiiparous & $18(52.9 \%)$ \\
Pregnancy care & \\
Yes & $22(64.7 \%)$ \\
Non & $10(29.4 \%)$ \\
Term of pregnancy & \\
$<33$ weeks of amenorrhea & $18(52.94 \%)$ \\
$>33$ weeks of amenorrhea & $16(47.05 \%)$ \\
Mode of delivery & \\
Vaginally & $33(97.1 \%)$ \\
Caesarean & $1(2.9 \%)$ \\
Infectious anamnesis & \\
Positive & $19(57.5 \%)$ \\
Negative & $14(42.4 \%)$ \\
\hline
\end{tabular}

(b)

\begin{tabular}{lc}
\hline Characteristics & Premature infants ${ }^{\mathbf{a}} \mathbf{N}=\mathbf{3 7}$ \\
\hline Sex & \\
Male & $16(43.2 \%)$ \\
Female & $21(56.8 \%)$ \\
Term pregnancy & \\
$<28$ WA & $1(2.7 \%)$ \\
$<33$ WA & $19(51.3 \%)$ \\
$<37$ WA & $17(45.9 \%)$ \\
Weight (grams) & \\
$<1500$ & $8(21.6 \%)$ \\
1500 to 2500 & $12(32.4 \%)$ \\
$>2500$ & $14(37.8 \%)$ \\
Apgar score at birth & \\
$<7$ & $6(16.2 \%)$ \\
$>7$ & $31(83.8 \%)$ \\
Birth form & \\
Premature infants referred & \\
Premature infants hospitalized in pediatrics & $5(13.5 \%)$ \\
Premature malformed & $14(37.8 \%)$ \\
Neonatal mortality & $3(6.1 \%)$ \\
Healthy premature given to the mother at birth & $6(16.2 \%)$ \\
\hline
\end{tabular}

${ }^{\mathrm{a}}$ Values are expressed as count and percentage. WA: weeks of amenorrhea. 
age is ranged between 24 and 36 weeks of amenorrhea. Late prematurity was observed in 17 cases (45.9\%), severe premature infants in 19 cases (51.3\%) and extremely preterm infants in 1 case (2.7\%). 16 (43.2\%) were boys and 21 (56.8\%) girls, with a male to female ratio 1.31. Only 8 premature infants (21.6 \%) had a weight birth less than 1500 grams.

\section{The fate of premature infants:}

Babies received neither surfactant nor caffeine at birth. We have identified 14 premature babies (37.8\%) who have been immediately hospitalized in paediatric service which has one incubator. Babies got a nasal oxygen therapy, a serum infusion of $10 \%$ glucose and antibiotics if premature is infected. These premature were tubefed whether breast-fed with bottle-feeding. 6 babies of them have passed away (16.2\%). Mortality is higher in low birth weight premature infants less than 1500 grams namely 50\% (3 cases) and it is around $83.3 \%$ (5 cases) for a term less than 33 weeks of gestation. Hyaline membrane disease is the main cause of death at $33.3 \%$ (2 cases), neonatal infection at 33.3\% (2 cases) and neonatal distress at 33.3\% (2 cases). 3 premature infants (21\%) have been referred from pediatrics service to the university hospital: one severe premature infants, one case suffering from the hyaline membrane disease and one congenital malformation case. 5 premature babies (36\%) have been given back to their mothers: 2 severe preterm babies, 1 case with neonatal infection and 2 cases with neonatal infant pain.

Only 21 healthy infants (56.7\%) among all premature infants have been immediately given back to their mothers at birth. Only 2 babies have been referred directly to the maternity ward at the university health center of Missour for respiratory distress and severe preterm birth.

\subsection{Factors of Premature Infants Morbidity (Table 2)}

The analysis of Table 2 shows that $63.2 \%$ of complicated premature infants are from more than $50 \mathrm{~km}$ of provincial hospital in Missour compared with $36.8 \%$ of healthy premature infants $(\mathrm{P}=0.002) .65 \%$ of complicated premature infants come from a pregnancy estimated at less than 33 weeks of amenorrhea against 35\% of healthy premature infants with a statistically significant difference $(P=0.007)$. Neonatal pain was observed in only 6 complicated preterm infants $(\mathrm{P}=0.003) .87 .5 \%$ had birth weight less than $1500 \mathrm{~g}$ versus $12.5 \%$ of healthy premature infants $(\mathrm{P}=0.002)$.

We have not found significant differences in other socio-demographic parameters (mother's age, gestity parity, pregnancy care, delivery way, infectious anamnesis and sex). The premature morbidity factors found in our study are mainly the origin of mother $>50 \mathrm{~km}$ of provincial hospital, gestational age of less than 33 weeks amenorrhea, a birth weight $<1500 \mathrm{~g}$ and neonatal pain.

\subsection{Risk Factors for Premature Infants (Table 2)}

Univaried analysis (Table 3) allowed raising some risk factors for premature infants including hypotrophy, positive infectious anamnesis and neonatal pain. $62.1 \%$ of premature infants had a birth weight less than $2500 \mathrm{~g}$ compared to $3 \%$ of new term infants $(\mathrm{P}<0.001) .16 .2 \%$ were premature suffering against $1.3 \%$ of new term infants $(\mathrm{P}<0.001)$. Positive infectious anamnesis was found in $56.8 \%$ against $29 \%$ of new premature infants $(\mathrm{P}=$ 0.001). We have not found a significant difference about age mother, gestity/parity, pregnancy care and sex of the newborn.

\section{Discussion}

The incidence of preterm birth has increased over the past three decades in developing countries, estimated at $7 \%$ in France and up to $12.7 \%$ in the United States [5] [6]. Prematurity remains higher in some African countries (15\% - 16\%) and fluctuates between $2 \%$ and $7 \%$ in some Western countries [1] [8] [12] [13]. During the study period, the preterm birth rate recorded in the maternity of Missour was 3.3\%. This figure makes $8 \%$ of all preterm births in Morocco [14].

Factors for neonatal morbidity of premature infants in our study were specially: origin of mother $>50 \mathrm{~km}$ from the provincial hospital center, term of pregnancy $<33$ weeks of amenorrhea, weight of new-born $<1500$ grams and perinatal asphyxia.

Prematurity but principally severe prematurity requires special care [6] [15] [16], its consequences could be significant on all newborn mortality. The emergence of a disability is linked to preterm birth. Indeed, the term of 
Table 2. Characteristics of groups of healthy and complicated premature infants ${ }^{\mathrm{a}}$.

\begin{tabular}{|c|c|c|c|}
\hline \multirow{2}{*}{ Characteristics } & \multicolumn{2}{|c|}{ Premature infants $N=37$} & \multirow{2}{*}{ P-value } \\
\hline & Complicated n = 16 & healthy $=21$ & \\
\hline \multicolumn{4}{|l|}{ Origin } \\
\hline$<50 \mathrm{~km}$ & $4(22.2 \%)$ & $14(77.8 \%)$ & 0.02 \\
\hline$>50 \mathrm{~km}$ & $12(63.2 \%)$ & $7(36.8 \%)$ & \\
\hline \multicolumn{4}{|l|}{ Age of mother } \\
\hline$<35$ years & $14(46.7 \%)$ & $16(53.3 \%)$ & 0,67 \\
\hline$>35$ years & $2(28.6 \%)$ & $5(71.4 \%)$ & $0.6 \%$ \\
\hline \multicolumn{4}{|l|}{ Gestity/Parity } \\
\hline Primiparous & 8 (44.4\%) & $10(55.6 \%)$ & 1 \\
\hline Multiparous & $8(42.1 \%)$ & $11(57.9 \%)$ & 1 \\
\hline \multicolumn{4}{|l|}{ Term of pregnancy } \\
\hline$<33$ weeks of amenorrhea & $13(65 \%)$ & $7(35.0 \%)$ & \\
\hline$>33$ weeks of amenorrhea & $3(17.6 \%)$ & $14(82.4 \%)$ & 0.007 \\
\hline \multicolumn{4}{|l|}{ Pregnancy care } \\
\hline Yes & $9(36 \%)$ & $16(64.0 \%)$ & 0.45 \\
\hline Non & $6(60 \%)$ & $4(40.0 \%)$ & \\
\hline \multicolumn{4}{|l|}{ Mode of delivery } \\
\hline vaginally & 15 (42.9\%) & 20 (57.1\%) & 1 \\
\hline Caesarean & $1(50.0 \%)$ & $1(50.0 \%)$ & 1 \\
\hline \multicolumn{4}{|l|}{ Infectious anamnesis } \\
\hline Positive & $10(47.6 \%)$ & 11 (52.4\%) & 0.396 \\
\hline Negative & $5(33.3 \%)$ & $10(66.7 \%)$ & \\
\hline \multicolumn{4}{|l|}{ Apgar } \\
\hline$>7$ & $9(31.0 \%)$ & $20(69.0 \%)$ & 0.003 \\
\hline$<7$ & $6(100.0 \%)$ & $0(0.0 \%)$ & \\
\hline \multicolumn{4}{|l|}{ Weight (grams) } \\
\hline$<1500 \mathrm{~g}$ & $7(87.5 \%)$ & $1(12.5 \%)$ & \\
\hline $1500-2500 \mathrm{~g}$ & $5(41.7 \%)$ & $7(58.3 \%)$ & 0.02 \\
\hline$>2500 \mathrm{~g}$ & $3(21.4 \%)$ & $11(78.6 \%)$ & 0.02 \\
\hline \multicolumn{4}{|l|}{ Sex } \\
\hline Male & $7(43.8 \%)$ & $9(56.3 \%)$ & 1 \\
\hline Female & $9(42.9 \%)$ & $12(57.1 \%)$ & 1 \\
\hline
\end{tabular}

${ }^{\mathrm{a}}$ Values are expressed as count and percentage. WA: weeks of amenorrhea.

gestation is a fundamental element in the prognosis of delivery that helps analyze the fetal lung maturation which is vital for the newborn. Preterm birth is the most common cause of perinatalmortality, causing almost $50 \%$ of neonatal deaths as it's the case in our study with a mortality rate of $83 \%$ in a gestation period less than 33 weeks [17]. Premature infants rate in the group of complicated premature infants $65 \%$ is different to the group of healthy controls 35\% with a significant P 0.007 (Table 2).

However, other factors are warning signs of mortality and morbidity of premature infants. There are significantly more deaths in the group with complicated premature infants cases under $1500 \mathrm{~g}$ at $87.5 \%$ compared to healthy controls, which is $12.5 \%(\mathrm{P}=0.02)$ (Table 2). The relation between weight and survival rate observed is clarified by the fact that the complications of low birth weight are even more lethal than when the birth weight decreases. We are talking here about low birth weight less than 2500 g; very low birth weight less than $1500 \mathrm{~g}$ and extremely low birth weight less than 1000 g corresponding to age groups: less than 37 weeks of amenorrhea, less than 33 weeks of amenorrhea and less than 28 weeks of amenorrhea. The main concern is when it comes to severe premature infants less than $1000 \mathrm{~g}$, whose prognosis is unfortunate (40\% mortality and 20\% neurological sequelae). These newborns were routinely forwarded to neonatal intensive care units [6] [18]. Premature infants of less than 1500 grams are the most vulnerable in our current context with a mortality rate of 50\% due to lack of resources allocated to optimally take care of preterm newborns.

There are those who suggest that prematurity is influenced by gender and sex meaning that male sex may in- 
Table 3. Characteristics of groups of premature and new-born at term in unvaried analysis ${ }^{\mathrm{a}}$.

\begin{tabular}{|c|c|c|c|}
\hline \multirow{2}{*}{ Characteristics } & \multicolumn{2}{|c|}{ Number (n) } & \multirow{2}{*}{ P-value } \\
\hline & A term $=1084$ & Premature $\mathbf{n}=\mathbf{3 7}$ & \\
\hline $\begin{array}{l}\text { Origin of mother } \\
<50 \mathrm{~km} \text { of Missour } \\
>50 \mathrm{~km} \text { from Missour }\end{array}$ & $\begin{array}{l}595(55.3 \%) \\
478(44.7 \%)\end{array}$ & $\begin{array}{l}18(48.6 \%) \\
19(51.4 \%)\end{array}$ & 0.737 \\
\hline $\begin{array}{l}\text { Age of mother } \\
<20 \text { years } \\
20 \text { - } 30 \text { years } \\
31-40 \text { years } \\
>40 \text { years }\end{array}$ & $\begin{array}{c}127(11.9 \%) \\
656(61.5 \%) \\
263(24.6 \%) \\
21(2 \%)\end{array}$ & $\begin{array}{c}1(2.7 \%) \\
26(70.3 \%) \\
10(27.0 \%) \\
0(0.0 \%)\end{array}$ & 0.326 \\
\hline $\begin{array}{l}\text { Gestity-Parity } \\
\text { Primiparous } \\
\text { Multiparous }\end{array}$ & $\begin{array}{l}510(47.7 \%) \\
560(52.3 \%)\end{array}$ & $\begin{array}{l}18(48.6 \%) \\
19(51.4 \%)\end{array}$ & 0.869 \\
\hline $\begin{array}{l}\text { Pregnancy care } \\
\text { Followed pregnancy } \\
\text { Not followed }\end{array}$ & $\begin{array}{l}576(54.9 \%) \\
474(45.1 \%)\end{array}$ & $\begin{array}{l}25 \text { (67.6\%) } \\
12(32.4 \%)\end{array}$ & 0.122 \\
\hline $\begin{array}{l}\text { Mode of delivery } \\
\text { vaginally } \\
\text { Caesarean }\end{array}$ & $\begin{array}{l}921(85.9 \%) \\
155(14.0 \%)\end{array}$ & $\begin{array}{c}35(94.6 \%) \\
2(5.4 \%)\end{array}$ & 0.050 \\
\hline $\begin{array}{l}\text { Infectious anamnesis } \\
\text { Positive } \\
\text { Negative }\end{array}$ & $\begin{array}{l}308(29 \%) \\
755(71 \%)\end{array}$ & $\begin{array}{l}21(56.8 \%) \\
16(43.2 \%)\end{array}$ & 0.001 \\
\hline $\begin{array}{l}\text { Weight of new-born }( \\
<2500 \mathrm{~g} \\
>2500 \mathrm{~g}\end{array}$ & $\begin{array}{c}33(3 \%) \\
1059(96.9 \%)\end{array}$ & $\begin{array}{l}23(62.1 \%) \\
14(37.8 \%)\end{array}$ & $<0.001$ \\
\hline $\begin{array}{l}\text { Sex of new-born } \\
\text { Male } \\
\text { Female }\end{array}$ & $\begin{array}{l}530(49.3 \%) \\
547(50.7 \%)\end{array}$ & $\begin{array}{l}16(43.2 \%) \\
21(56.8 \%)\end{array}$ & 0.507 \\
\hline $\begin{array}{l}\text { Apgar at birth } \\
>7 \\
<7\end{array}$ & $\begin{array}{c}1060(98.6 \%) \\
15(1.3 \%)\end{array}$ & $\begin{array}{c}31(83.8 \%) \\
6(16.2 \%)\end{array}$ & $<0.001$ \\
\hline
\end{tabular}

${ }^{\mathrm{a}}$ Values are expressed as count and percentage.

crease the likelihood of preterm birth more than female one, while others nullify such hypothesis [19] [20]. However, we did not observe any significant difference in our study.

Spontaneous preterm deliveries represent $70 \%$ to $80 \%$ of preterm births. Several factors such as physical and psychological stress, past history of previous spontaneous preterm births, fetal death or low birth weight and a premature rupture of membranes in $20 \%-45 \%$ of cases are the cause of these deliveries [21]-[24]. However, only multiple pregnancies would increase significantly in recent decades [19] given the frequent use of assisted reproductive technologies. Also, the woman's age during the medically assisted reproduction is a probable factor in multiple births. The risk of prematurity is ten times higher in the case of twinning than during a single pregnancy, which is also the origin of enhancement in morbidity and mortality of twins [25]-[27]. Our figures are almost similar to those described in the literature with a rate of spontaneous preterm delivery around $95 \%$ linked to premature rupture of membranes in $40 \%$ of cases. However, in our sample the conventional assumption that says that the risk of preterm birth is 15 times higher in case of multiple pregnancy before 35 weeks of amenorrhea could not be verified given that the number of twin pregnancies collected is low: $8 \%$ namely 3 cases. Analysis of our results has shown that only 6 women were over 35 years, that none of them could benefit from a medically assisted reproduction technique usually not carried out in the maternity ward in Missour (Table 1).

However, there is currently an increase in induced preterm birth (35\% - 40\%) which may engage maternal or fetal prognosis. Small-for gestational-age enfant, pre-eclampsia objectified in 2 of our parturient women and bleedings (Abruptio placentae...) [28] [29] are the most often encountered.

Underprivileged areas of origin are responsible for spontaneous deliveries to occur [4]. Our study has noticed a significant difference between the group of complicated premature infants around $63.2 \%$ that are from areas 
located about more than $50 \mathrm{~km}$ from the province and those in good health around $77.8 \%$ from areas less than 50 $\mathrm{km}(\mathrm{P}=0.02)$ (Table 2).

A regional perinatal care organization is responsible for the improvement of preterm infant's survival and the assignment of premature infants with complex care needs to centers type III disposing of a neonatal life support unit. Similarly, the early transfer of women to specialized care centers when there is a risk of premature delivery is urgent [3] [21]. Yet many studies have shown significant reduction in neonatal mortality among severe premature infants born in a neonatal intensive care center (in born) quite the contrary to those transferred to intensive care after birth (out born) [30] [31]. The care of preterm infants must be straight after birth and must take into account the special characteristics of this category of newborns primarily based on hypothermia treatment and the maintenance and stabilization of the vital functions. Still, an in utero transfer is often confronted with psychological factors of patients and their families and the activities of organizational nature of the maternities of level one. Bear in mind the risk of delivery during the transfer [32].

Note that a severe preterm delivery may occur before the expansion equals $10 \mathrm{~cm}$. The use of ultrasound to screen the length of the cervix is more efficient than vaginal examination. It allows detecting parturient women with increased risks of preterm delivery, which would require great care (intravenous tocolysis, corticoids, an in utero transfer). It is more convenient to delay the transfer in utero if the cervix exceeds $27 \mathrm{~mm}$ and that the woman would give birth later [33].

The regulation of transfer in utero is organized by the agreement between the referring doctor, the regulating doctor and the mobile emergency doctor which allows the midwives to ensure all transfers by means of approved protocols within the health network. The ambulance service (SAMU) is the center of a coordinated device of emergency care and responsible to connect the referring and the receiving doctor [33].

Three classes of transportation must be present:

1 (Single ambulance): the transport team consists of 2 people with at least one holding a certificate of ambulance competence.

2 (Inter-hospital transfer nurse): 3 people including at least one holder of an ambulance competence certificate and one nursing staff (nurse) or medical staff (midwife).

3 (Medicalized transfer by the SMUR (specialist mobile emergency unit)) supervised by a senior health professional accompanied by a nurse and an ambulance driver.

Transfers of class 1 or 2 are not carried out by doctor, they are organized by the agreement between the referring and hosting doctor that refer and that host the patient [33].

The organization of providing care in our study context has considerable functioning problems primarily due to a mismatch between supply and demand and to non compliance with the applicable rules and regulations of the care system. This is exacerbated by inequalities in health care facilities from a community to another; and by the issues of access to local or provincial health services. $11.5 \%$ of the population of Missour is located in an area where healthcare services are difficult to access during winter. The provincial hospital center in Missour does not dispose of either an intensive care unit or a neonatal resuscitation unit. All preterm babies in immediate vital distress are transferred to the nearest university health center of the Fez city located about 200km from the province of Missour in the only ambulance available in the province. The ambulance is poorly equipped and does not dispose of an incubator. It should also be noted that there is a lack of availability of places in health care centers for premature infants.

Regionalization guiding principles as a basis for close monitoring pregnant women and the administration of antenatal corticosteroids to accelerate fetal maturation before birth [3] [34]. Glucocorticoids are very effective in reducing the risk of hyaline membrane disease by $25 \%$ to $10 \%$ during a gestational age of 26 to 34 weeks of amenorrhea [35]. According to literature data, betamethasone was routine for any birth expected between 26 and 34 weeks of amenorrhea even in the case of infection risk and was administrated intramuscularly in our study at a dosage of $6 \mathrm{mg} / 12$ hours over 48 hours [36]-[39].

The midwife may play a key role in prevention. Women can get an interview with the midwife in the early stage pregnancy to identify the main risk factors and initiate a prevention approach. The monthly inspection of the cervix by vaginal examination is the way to detect the risk of a premature delivery of a future mother who should be immediately put to bed rest. She would be possibly referred to a suitable hospital. PMI (mother and child care) Midwives can also visit parturient at home and gather information about their social and psychological background and housing conditions [40]. It would also be essential to involve midwives in preterm birth prevention programs and kangaroo cares by teaching them directives best suited for local culture. 
Some patients may meet their midwife for the first time when they arrive at the hospital in Missour in case there isn't any possible prenatal care in their area or when the health facility does not offer a midwife consultation. On the other hand, the coverage by gynecologists, obstetricians and midwives (only two gynecologists in the maternity ward in the hospital in Missour which is a type II maternity) differs from area to area over the national territory. A number of parturient women were monitored during the perinatal period by a general practitioner instead of a medical specialist.

The influence of poverty has a detrimental impact on the health status and the prevalence of preterm birth and small-for gestational-age enfant. Unemployed women or with no social security only reach for gynecological care services and prenatal diagnosis at very late stage due to either the difficulty to access to health care services or the refusal of treatment due to lack of financial means [41] [42]. The retrospective nature of this study does not allow us to analyze data in a relevant way. Data collection in patient records was not systematic particularly of elements on the social situation (income, housing conditions, health security and social and family supports....). However, the impact of social vulnerability on preterm birth is inevitable in Missour. Our results show that these women benefit from fewer consultations and suffer from more health problems during pregnancy.

Most needy patients must have easy access to health care. Emergency services, maternity hospitals and health centers should offer women in vulnerable social circumstances appropriate reception units. However, it would be essential to set up programs to educate people, train healthcare professionals in social action on the risks of pregnancy and make training of nursing staff on a monthly basis to detect preterm birth risk factors including socio-economic, financial difficulties and cervical incompetence: Spontaneous preterm birth mainly before 34 weeks of gestation [43] was reduced very significantly thanks to the use of cervical pessary. Routine administration of progesterone introduced orally or vaginally at the beginning of the 2nd quarter is also effective [44]. In case of preterm delivery threats, as is the case in Missour, tocolytic and beta-agonist treatments are the most frequently used [45].

However, it is established that infection most often makes tocolysis harmful to infant [46] [47]. Its effectiveness beyond 48 hours is not supported with certified test results [45] [48]. Successful treatment of any urinary or vaginal infection is therefore fundamental, which was introduced from the beginning in our study context [21].

Other factors influencing the survival rate of preterm infants with a neonatal mortality rate of $33.3 \%$ in our work are: apgar score at 5 minutes, neonatal respiratory distress syndrome and neonatal infection (Table 2, Table 3).

Spontaneous preterm birth causes more deaths due to neurological complications especially cerebral hemorrhage and neonatal pain with a significant difference of $25 \%$ compared to the group of healthy premature infants in our study, immediately returned back to their mothers after birth.

Respiratory distress syndrome of premature infants is mainly related to hyaline membrane disease due to insufficient production of pulmonary surfactant affecting $25 \%$ of our premature infants, which approaches the international figures of $10 \%$ to $40 \%$ mainly among women of less than 32 weeks of gestation [49]-[51]. Moreover, the risk of developing a hyaline membrane disease is important compared to pre-eclampsia among premature infants less than $2 \mathrm{~kg}$ [52]. At the very time and despite the substitution of exogenous surfactant, the average mortality is around $20 \%$ [21].

Our results regarding neonatal infection (19\%) confirm the results recorded (24\% - 43\%) [53]. Asymptomatic bacteriuria and bacterial vaginosis in pregnancy are associated with the occurrence of preterm delivery [54] [55]. Routine screening of vaginal bacteria in early pregnancy was not regularly initiated to our parturient women; the thing that did not allow us to calculate or estimate the effects of bacterial vaginosis. Placental cultures and anatomopathological examination of the placenta and membranes were not mandatory. Not a single patient had taken advantage of vaginal tests, amniotic fluid tests, cytobacteriological examination of the urine or tests to detect Procalcitonin in the cord blood to look for signs of infection. An antibiotic treatment was administrated to patients who have given birth spontaneously with clinical and biological infection criteria (NFS, CRP). Nevertheless, many studies suggest that there is often a connection between bacterial vaginosis and preterm birth especially among women with a variant of the gene coding for alpha TNF. It would be interesting to set up research studies to detect in the best possible way the interactions between factor types including psycho-social, biological and genetic factors for better management of high-risk women [15].

\section{Limitation of the Study}

The present study is the first to address the issue of care for premature in Moroccan provincial hospital. There 
are two noteworthy limitations of this study: the number of patients and controls enrolled was small and it was conducted in a shorter period of time than is typical of studies which focus on the similar issues. Nevertheless, one of its strengths lies in providing a platform to bring together more collaborators (clinicians and researchers) to carry out a more in-depth study.

\section{Conclusion}

Preterm birth is serious and not risk-free especially for extremely preterm birth and low birth weight preterm infants. The survival rate of preterm babies is improved by the use of appropriate equipment in our neonatal unit by means of ventilation and artificial surfactant. Geographical and financial constraints of in utero transfers should be integrated into decision-making processes. However, our work emphasizes the vital importance of the "Kangaroo mother care" method in environments where only poor traditional healthcare is available.

\section{Acknowledgements}

We thank all participants for taking part in this study.

\section{Competing Interests}

The authors declare that they have no competing interests.

\section{References}

[1] Amri, F., Fatnassi, R., Negra, S. and Khammari, S. (2008) Prise en charge du nouveau-né prématuré. [Management of Premature Neonates.] Journal de pédiatrie et de puériculture, 21, 227-231. http://dx.doi.org/10.1016/j.jpp.2008.04.019

[2] Moutquin, J.-M. (2003) Classification and Heterogeneity of Preterm Birth. An International Journal of Obstetrics and Gynaecology, 110, 30-33. http://dx.doi.org/10.1016/S1470-0328(03)00021-1

[3] Simeoni, U. (2014) Prématurité: De la période périnatale à l’âge adulte. [Prematurity: The Perinatal Period in Adulthood.] Elsevier Masson SAS.

[4] Benbassa, A., Tournaire, M. and Nathan, G. (2004) Prématurité. D’après le guide de surveillance de la grossesse de l'ANDEM, 4. Prematurity. According to the Monitoring of Pregnancy Guide ANDEM, 4.

[5] Kieffer, F., Soudée, S. and Groslier, M.-H. (2011) Prématurité et handicap. [Prematurity and Handicap.] Soins Pédiatrie-Puériculture, 263.

[6] Lacroze, V. (2014) Prématurité: Définitions, épidémiologie, étiopathogénie, organisation des soins. [Prematurity: Definitions, Epidemiology, Pathogenesis, Care Organization.] Elsevier Masson SAS.

[7] Pattinson, R.C. (2004) Are Deaths Due to Prematurity Avoidable in Developing Countries? Tropical Doctor, 34, 7-10.

[8] World Health Organization (2007) Maternal Mortality in 2005: Estimates Developed by WHO, UNICEF, UNFPA, and the World Bank. World Health Organization, Geneva.

[9] Beck, S., Wojdyla, D., Say, L., Betran, A.P., Merialdi, M., Requejo, J.H., et al. (2010) The Worldwide Incidence of Preterm Birth: A Systemic Review of Maternal Mortality and Morbidity. Bulletin of the World Health Organization, 88, 31-38. http://dx.doi.org/10.2471/BLT.08.062554

[10] Goldenberg, R.L., Culhane, J.F., Lams, J.D. and Romero, R. (2008) Epidemiology and Causes of Preterm Birth. Lancet, 371, 75-84. http://dx.doi.org/10.1016/S0140-6736(08)60074-4

[11] Wilson, N.W., Couper, I.D., De Vries, E., Reid, S., Fish, T. and Marais, B.J. (2009) A Critical Review of Interventions to Redress the Inequitable Distribution of Healthcare Professionals to Rural and Remote Areas. Rural and Remote Health, 9, 1060.

[12] Ye, D., Kam, K.L., Sanou, T., Traore, A., et al. (1999) Etude épidémiologique et évolutive de la prématurité dans l'unité de néonatologie du CHN-YO de Ouagadougou. [Epidemiological and Evolutionary Study of Prematurity in the Neonatal Unit of the CHN-YO Ouagadougou.] Annales de Pédiatrie, 46, 43-48.

[13] Ganga Zandzou, P.S., Mayanda, H.F. and Miakayizila, P. (1999) Evolution des facteurs associés à la prématurité après 5 mois de crise politique à Brazzaville. [Evolution of the Factors Associated with Preterm Birth after Five Months of Political Crisis in Brazzaville.] Annales de Pédiatrie, 46, 723-729.

[14] Barkat, A., MdaghriAlaoui, A., Hamdani, S. and Lamdouar Bouazzaoui, N. (2004) Problématique de la prise en charge de la prématurité au Maroc. Expérience du service de Néonatologie Centre National de Référence en Néonatologie, Hôpital d'enfants, Rabat. [Problems of Management of Prematurity in Morocco.] Experience of a National Reference 
Center for Neonatology and Nutrition Rabat Children's Hospital, Jeunes du Maroc, 4 p.

[15] Ancel, P.-Y. (2008) La grande prématurité en 2008: Questions et perspectives de recherche. [Verypretermbirth in 2008: Questions and Perspectives.] Archives de Pédiatrie, 15, 598-601. http://dx.doi.org/10.1016/S0929-693X(08)71846-3

[16] Chiabi, A., Mah, E., Ntsama Essomba, M.-J., Nguefack, S., Mbonda, E. and Tchokoteu, P.-F. (2013) Facteurs associés à la survie des nouveau-nés de très faible poids de naissance à l’hôpital gynéco-obstétrique et pédiatrique de Yaoundé, Cameroun. Risk Factors for Neonatal Mortality at the Yaounde Gynaeco-Obstetric and Pediatric Hospital, Cameroon Elsevier Masson SAS.

[17] Vaast, P. and Puech, F. (2001) Sécurité des transferts in utero d'indication fœtale [Security of Transfers in Uterofetal Indication.] Journal de Gynécologie Obstétrique et Biologie de la Reproduction, 30, 525-528.

[18] Hoekstra, R.E., Ferrara, B., Couser, R.J., Payne, N.R. and Connett, J.-E. (2004) Survival and Long-Term Neuro-Developmental Outcome of Extremely Premature Infants Born at 23 - 26 Weeks Gestational Age at a Tertiary Center. Pediatrics, 113, 1-6.

[19] Lequien, P. (2004) Très grande prématurité: Optimisme ou pessimisme? [Extreme Prematurity: Optimism or Pessimism?.] Archives de Pédiatrie, 11, 1295-1298. http://dx.doi.org/10.1016/S0929-693X(04)00390-2

[20] Favre, A., Joly, N., Blond, M.H., Buisson, P., Cardoso, T. and Delattre, P. (2003) Devenir médicosocial à l’âge de 2 ans des grands prématurés pris en charge au centre hospitalier de Cayenne en 1998 [Outcome at 2 Years of Very Premature Infants Cared at the Hospital of Cayenne in 1998.] Archives de Pédiatrie, 10, 596-603. http://dx.doi.org/10.1016/S0929-693X(03)00297-5

[21] Castaigne, V., Picone, O. and Frydman, R. (2005) Accouchement du prématuré [Delivery of Preterm Infants.] EMC Gynécologie-Obstétrique, 2, 354-363. http://dx.doi.org/10.1016/j.emcgo.2005.09.001

[22] Senate, M.V., Tsatsaris, V., Ville, Y. and Fernandez, H. (1999) Menace d'accouchement prématuré. Preterm Labor Threat. Encycl Méd Chir, Elsevier, Paris, Urgences, 24-213-A-20, 17 p.

[23] Périlleau-Boichut, C., Voluménie, J.-L. and Fléchelles, O. (2014) Facteurs de risque de prématurité spontanée avant 30 SA en Martinique: Etude cas témoins [Risk Factors Associated with Spontaneous Preterm Deliveries Before 30 Weeks in Martinique F.W.I.: A Case-Control Study.] Journal de Gynécologie Obstétrique et Biologie de la Reproduction, 43, 610-615. http://dx.doi.org/10.1016/j.jgyn.2013.08.008

[24] Morin, M., Arnaud, C., Germany, L. and Vayssiere, C. (2012) Grande prématurité: Evolution de 1994 à 2006 [Preterm birth: Evolution 1994 to 2006.] Gynécologie Obstétrique \& Fertilité, 40, 746-752. http://dx.doi.org/10.1016/j.gyobfe.2012.05.007

[25] Minakami, H., Honma, Y., Matsubara, S., Uchida, A., Shiraishi, H. and Sato, I. (1999) Effects of Placental Chorionicity on Outcome in Twin Pregnancies. A Cohort Study. The Journal of Reproductive Medicine, 44, 595-600.

[26] Boog, G. (1994) La mort in utero d’un jumeau. Intrauterinedeath of a twin. Société de Médecine périnatale, Ed 24ème journées nationales de médecine périnatale. Arnette, Paris, 51-62.

[27] Debillon, T. (2004) Mortalité et morbidité chez les jumeaux [Mortality and Morbidity among Twins.] Archives de Pédiatrie, 11, 659-660. http://dx.doi.org/10.1016/j.arcped.2004.03.086

[28] Zupan-Simunek, V. (2010) Pronostic des nouveau-nés de mère prééclamptique [Prognosis in Newborns after Mother’s Preeclampsia.] Annales Françaises d'Anesthésie et de Réanimation, 29, e135-e139. http://dx.doi.org/10.1016/j.annfar.2010.03.013

[29] Zeitlin, J., Ancel, P.Y., Larroque, B. and Kaminski, M., The EPIPAGE Study (2004) Fetal Sex and Indicated Very Preterm Birth: Results of the EPIPAGE Study. American Journal of Obstetrics \& Gynecology, 190, 1322-1325. http://dx.doi.org/10.1016/j.ajog.2003.10.703

[30] Ancel, P.Y., Du Mazaubrun, C. and Breart, G. (2001) Grossesses multiples, lieu de naissance et mortalité des grands prématurés: Premiers résultats d'EPIPAGE en Ile de France [Multiple Pregnancy, Place of Delivery and Mortality in Very Premature Infants: Early Results from the EPIPAGE Cohort in Ile-de-France Area.] Journal de Gynécologie Obstétrique et Biologie de la Reproduction, 30, 48-54.

[31] Truffert, P., Goujard, J., Dehan, M., Vodovar, M. and Breart, G. (1998) Outborn Status with a Medical Neonatal Transport Service and Survival without Disability Has 2 Years. European Journal of Obstetrics \& Gynecology and Reproductive Biology, 79, 13-18. http://dx.doi.org/10.1016/S0301-2115(97)00243-1

[32] Audibert, F., Vial, M., Taylor, S., Curbrat, V., Troche, G., Benhamou, D., et al. (1999) Régionalisation des soins périnatals et transferts in utero. [Regionalization of Perinatal Care and in utero Referrals.] La Presse Médicale, 28, 2109- 2112.

[33] Gilles, B. (2009) Régulation des transferts in utéro et réseau de transfert périnatal. 51ème Congrès national d'anesthésieet de reanimation [Regulation of Transfers in Utero and Perinatal Transfer Network Médecine-Urgences Vitales.] 51th National Congress of Anesthesia and Resuscitation, Elsevier Masson SAS. 
[34] Paris, NPHS edn (1994) La sécurité et la qualité de la grossesse et de la naissance. Pour un nouveau plan de périnatalité. Collection Avis et Rapports. Haut comité de la santé publique, ministère des affaires sociales, de la santé et de la ville.safety and quality of pregnancy and birth. For a new perinatal plan. Collection Notices and Reports. High Committee of Public Health, Ministry of Social Affairs, Health and the City.

[35] Collinot, H. and Azria, E. (2013) Prévention de l'accouchement prématuré par pessaire [Cervical Pessary for Preventing Preterm Birth.] Gynécologie Obstétrique \& Fertilité, 41, 260-261. http://dx.doi.org/10.1016/j.gyobfe.2013.02.014

[36] Crowley, P.A. (1995) Antenatal Corticosteroid Therapy: A Meta-Analysis of the Randomized Trials. American Journal of Obstetrics \& Gynecology, 173, 322-335. http://dx.doi.org/10.1016/0002-9378(95)90222-8

[37] Penney, G.C. (1999) Antenatal Corticosteroids to Prevent Respiratory Distress Syndrome. RCOG, Guidelines. http://www.rcog.org.uk

[38] Hamon, I. and Hascoet, J.M. (2001) La corticothérapie périnatale: Actualités [Perinatal Corticosteroid: Currentevents.] Journal de Gynécologie Obstétrique et Biologie de la Reproduction, 30, 50-53.

[39] Schmitz, T. (2010) Corticoïdes prénatals: Effets néonatals d’une deuxième cure [Antenatal Corticosteroids: Neonatal Effects of a Second Course.] Archives de Pédiatrie, 17, S101-S104. http://dx.doi.org/10.1016/S0929-693X(10)70908-8

[40] Catherine Verneuil (2012) Pour la sage-femme, la menace d'accouchement prématuré doit être une préoccupation permanente [For the Midwife, the Threat of Premature Birth Should be an Ongoing concern.] Vocation Sage-Femme, 11, 8-9.

[41] Mahieu-Caputo, D. (2010) Prise en charge des femmes enceintes et nouveau-nés en situation de vulnérabilité sociale: Faut-il une prise en charge spécifique? [Pregnancy and Social Vulnerability: The Need for Specific Care.] Gynécologie Obstétrique \& Fertilité, 38, 83-91. http://dx.doi.org/10.1016/j.gyobfe.2009.09.014

[42] Khoshnood, B., Vigan, C., Blondel, B., Vodovar, V., Cadio, E. and Goffinet, F. (2008) Long Term Trends for SocioEconomic Differences in Prenatal Diagnosis of Down Syndrome: Diffusion of Services or Persistence of Disparities? BJOG: An International Journal of Obstetrics \& Gynaecology, 115, 1087-1095. http://dx.doi.org/10.1111/j.1471-0528.2008.01794.x

[43] Sentilhes, L., Descamps, P. and Legendre, G. (2014) Pessaire et prévention de l’accouchement prématuré [Cervical Pessary and Prevention of Preterm Birth.] Gynécologie Obstétrique \& Fertilité, 42, 38-44. http://dx.doi.org/10.1016/j.gyobfe.2013.10.009

[44] Langer, B., Gaudineau, A., Sananes, N. and Fritz, G. (2013) Prise en charge des patientes ayant un antécédent d'avortement tardif ou d'accouchement très prématuré [Management of Patients with a History of Late Abortion or Very Premature Delivery.] Gynécologie Obstétrique \& Fertilité, 41, 123-129. http://dx.doi.org/10.1016/j.gyobfe.2012.12.016

[45] Duley, L.M. (1999) Tocolytic Drugs for Women in Preterm Labor. RCOG, Guidelines. http://www.rcog.org.uk

[46] Spinillo, A., Capuzzo, E., Stronati, M., Ometto, A., De Santolo, A. and Acciano, S. (1998) Obstetric Risk Factors for Periventricular Leukomalacia among Preterm Infants. BJOG: An International Journal of Obstetrics \& Gynaecology, 105, 865-867. http://dx.doi.org/10.1111/j.1471-0528.1998.tb10231.x

[47] Baud, O., Ville, Y., Zupan, V., Boithias, C., Lacaze-Masmonteil, T., Gabilan, J.C., et al. (1998) Are Neonatal Brain Lesions Due to Intrauterine Infection Related to Mode of Delivery? BJOG: An International Journal of Obstetrics \& Gynaecology, 105, 121-124. http://dx.doi.org/10.1111/j.1471-0528.1998.tb09363.x

[48] Carbonne, B., Tsatsaris, V., Lejeune, V. and Goffinet, F. (2001) Quels tocolytiques utilisés en 2001 [Which Tocolytics Should Be Used in 2001.] Journal de Gynécologie Obstétrique et Biologie de la Reproduction, 30, 89-93.

[49] De Gamarra, E. (1999) Prématurité. Pédiatrie en maternité [Prematurity. Pediatric Maternity.] Flammarion, Paris, 167-176.

[50] Truffert, P., Maillard, F. and Burguet, A., for the Group EPIPAGE (2001) Morbidité pulmonaire du grand prématuré: incidence et prise en charge, cohorte EPIPAGE 1997. [Pulmonary Morbidity of Extremely Premature: Incidence and Management, EPIPAGE Cohort.] 31es Journées de médecine périnatale, Arnette, Paris, 175-182.

[51] Cherif, A., Ben Jemaa, W., Kacem, S., Guellouze, N., Jebnoun, S. and Khrouf, N. (2008) La prééclampsie augmente le risque de maladie des membranes hyalines chez le prématuré: Etude rétrospective contrôlée [Preeclampsia Increases the Risk of Hyaline Membrane Disease in Premature Infant: A Retrospective Controlled Study.] Journal de Gynécologie Obstétrique et Biologie de la Reproduction, 37, 597-601. http://dx.doi.org/10.1016/j.jgyn.2008.03.008

[52] Villar, J., Carroli, G., Wojdyla, D., Abalos, E., Giordano, D., Ba’aqeel, H., et al. (2006) Preeclampsia, Gestational Hypertension and Intrauterine Growth Restriction, Related or Independent Conditions? American Journal of Obstetrics \& Gynecology, 194, 921-931. http://dx.doi.org/10.1016/j.ajog.2005.10.813

[53] Hack, M., Taylor, H.G., Klien, N. and Mercuri-Minich, N. (2000) Functional Limitations and Special Health Care Needs of 10- to 14-Year-Old Children Weighing Less than 750 Grams at Birth. Pediatrics, 106, 554-560. 
http://dx.doi.org/10.1542/peds.106.3.554

[54] Slattery, M.M. and Morrison, J.J. (2002) Preterm Delivery. The Lancet, 360, 1489-1497. http://dx.doi.org/10.1016/S0140-6736(02)11476-0

[55] Zeitlin, J., Bucourt, M., Rivera, L., Topuz, B. and Papiernik, E. (2004) Preterm Birth and Maternal Country of Birth in a French District with a Multiethnic Population. BJOG: An International Journal of Obstetrics \& Gynaecology, 111, 849-855. http://dx.doi.org/10.1111/j.1471-0528.2004.00184.x 